\title{
A Program for Staff Reading
}

Dr. Muller is director of libraries, Southern Illinois University.

W

ELL-READ librarians seem to be in danger of becoming extinct. This trend might be related to the widely accepted policy of not permitting any protracted library staff reading on paid library time, with the exception of the reading of professional library literature, such as book reviews, catalogs, and articles on library techniques. It has been suggested that the responsibility for preventing the extinction of well-read librarians rests with the library administrator rather than with his staff. However, the policy that all library staff reading must be done outside library walls seems rather deeply entrenched. Hence, any library administrator who dared to deviate from that policy by requiring his staff to read during working hours would invite censure from his superiors.

For the sake of clarifying the issue, let us assume that a head librarian did decide to take a chance and proceeded to establish an official reading program for his staff. Let us assume that the program will be limited to the professional staff, with no differentiation between those assigned to reader services and technical processing services, respectively.

It is conceivable that a reading specialist or a committee composed of top-ranking library staff members would select the most significant titles from the point of view of the actual or desirable reading interests of library users. Such titles might then be assigned to the staff for reading. A visible file catalog or posters might make it known to the public what titles have been read and by whom on the library staff. If a library user wished to obtain a first-hand reaction to a book, he would attempt to locate the librarian who appeared in the file or catalog as having read the book. Staff-written book annotations could be posted in the library and staff members would be urged to seek opportunities for giving book talks both in the library and before organized groups.

Such immediate service, however, represents only a minor benefit of a reading program. Published reviews written by professional reviewers will often be superior in quality to annotations written by members of a library staff. - The more important result of a staff reading program is less tangible than providing immediate service. What the program would create is a staff of librarians who read and who know books and who may thus be in a better position to stimulate reading in others. Through genuine enthusiasm for some of the books they have personally read, they may infect library patrons with a desire for reading; and it is the book-steeped atmosphere thus engendered that would also save the soul of many a library employee and encourage others to join the profession.

\section{Cost}

One-fourth of the available professional staff time, although obviously an arbitrary fraction, is probably the minimum time to be set aside for consecutive reading if results are to be noticeable. Under the plan whereby the reading is distributed among all members of the professional staff, each would spend no more than thirty hours a week performing regular library duties, such as book selection, cataloging, reference serv- 
ice, scheduling and supervising of clerks, publicity, preparing bibliographies, securing inter-library loans, preparing statistical reports, analyzing circulation trends, promoting audio-visual materials, etc. The remaining ten hours of a normal work week would be devoted to reading behind the scenes in the most comfortable surroundings, and completely undisturbed.

If the present work load of a library cannot be reduced, the introduction of a staff reading program, consuming $25 \%$ of staff time, would require an increase of about $33 \%$ in the professional salary budget of the library. For instance, a library employing six librarians would have to add two librarians if every member of the enlarged staff were required to spend onefourth of her or his scheduled library time as a participant in the officially sanctioned reading program. Assuming that the library spends around $40 \%$ of its total budget for salaries of professional librarians, the required increase in the total library budget would amount to about $13 \%$. Budget divisions vary, of course, from library to library. In college and university libraries, the spending of 50 to $60 \%$ of the total library budget for salaries and wages is considered normal. ${ }^{1}$ Of this percentage, about two-thirds would be spent for professional salaries and one-third for clerktypists and student help. An official reading program would cover only the professional staff. In public libraries, the percentage of the budget assigned to professional salaries is probably lower than in college libraries of the same size. Hence the percentage increase required to pay for an official reading program would probably be less than $13 \%$ of the total budget in public libraries.

As long as a forty-hour week is ac-

1 Guy R. Lyle, The Administration of the College Library, 2nd ed., New York, H. W. Wilson, 1949, p. 462 . cepted as the standard for most professional library employees, the creation of a wellread professional library staff requires either a substantial curtailment of the general library program or a sharp increase in the library staff. $^{2}$ Urging librarians to read more during their leisure hours is not likely to be too fruitful and can hardly be defended as a sound personnel policy.

It goes without saying that most librarians have always devoted a much larger than average portion of their leisure hours to the pursuit of reading. Such reading. however, should not be of the kind that is required as essential equipment for satisfactory work performance. A children's librarian should not be required to peruse children's books at home; a business librarian should not have to spend her leisure hours browsing through books and magazines related to business. Leisure hours should be devoted to the kind of reading from which the librarian derives personal pleasure; and such reading is not necessarily related to the requirements of the job.

Library administrators are unrealistic if they think they can maintain a literate library staff without added financial support. Whether an increase of $13 \%$ in a library's budget is too high a price to pay is, of course, for the governing authority to decide. It is up to the library administrator, however, to make the necessary recommendation.

In the past, when increased funds have become available, librarians as well as their professional associations have usually been interested in extension of library service. The time may soon be here when efforts will instead be devoted to qualitative improve-

2 According to Economic Status of Library Personnel, 1949 (Chicago: American Library Association, 1950), pp. I I and 78, 68 per cent of all professional library employees in the U.S. observed a scheduled work week of 38 to 40 hours; $2 \mathrm{I}$ per cent worked fewer than 38 hours a week; and I I per cent worked 4I hours or more a week. The 40-hour week was the most common single a s?hedule
colleges. 
ment of existing library service rather than the cultivation of new territory. An authorized staff reading program, costly as it is, may be expected to raise the quality of library service.

\section{Benefits}

Lest illusions be created, it is well to be as specific as possible about the benefits to be derived from a staff reading program. If we assume a work year of 48 weeks, IO hours of reading a week add up to 480 hours a year for each professional librarian. How much reading could be accomplished in 480 hours would depend on the kinds of books read. At a reading rate of 40 pages an hour for ordinary fiction and assuming an average length of 400 pages per book, 48 books of fiction could perhaps be read in a year. For nonfiction, the number of books might be between 30 and 35 . A selection that included nonfiction as well as fiction might result in an average of about 40 books a year read on library time.

At first sight, this figure of 40 books a year does not seem very impressive in relation to the annual output of American publishers. $^{3} \quad$ However, if 40 books are multiplied by the number of staff members in a given library, it is conceivable that a plan could be worked out whereby all the most noteworthy new books could be read by even a relatively small staff, provided that no two staff members would read the same book on library time. Our hypothetical staff of eight professional librarians could read 320 different books a year, which would cover quite a respectable range of literary form and subject matter. The details of assignment would, of course, have to be worked out differently for each different library.

3 The total number of new books, exclusive of new editions, published in the U. S. was 8,634 in 1950 and 8,460 in 1949 , as reported in Publishers' Weekly, 159: 240 (Jan. 20, I95 I).
The conscientious individual librarian, who reads 40 books on library time, could not reasonably be expected to read more than another 60 books on his own time; such reading would be of the unrequired and non-occupational type, which Irwin Edman recently extolled in the Fifteenth Bowker Lecture. ${ }^{4}$

Estimates as to how much an individual working person can read during a year vary. Dean John E. Burchard, an ex-librarian, recently estimated that a person reading 12 hours every week, 3 hours an evening, 4 evenings a week, could digest roo volumes a year, although he indicated that the average professional person probably devotes parhaps two-fifths of such reading time or the equivalent of 40 volumes, to professional reading and news magazines. ${ }^{5}$ Thus 60 volumes would seem to be a fair estimate for independent recreational and cultural reading. The average college-educated person probably reads fewer than 60 volumes a year by far; but many librarians, dedicated as they are professionally to the promotion of the pursuit of recreational and educational reading, might be inclined to read more than the average. By carefully observing a reading schedule during their leisure hours, they could be expected to digest 60 volumes a year in addition to the 40 volumes read on library time, thus chalking up a total reading record of 100 volumes a year.

A total of 100 volumes a year represents a reasonable rather than a maximum estimate of a person's likely consumption of reading matter. A figure of 500 volumes a year was reported for Donald Gordon, a professional book appraiser of the world's largest book wholesale firm for over 20

\footnotetext{
4Publishers' Weekly, I 58:1852 (Oct. 21, 1950): “The inability, and lack of time, to read is especially to be noticed," Professor Edman said, "among those whose noticed, Prof essor Edman said,",
professional concern is with books."

"Multum in Parvo" in M. I. T. Library Annual, I 948 , p. I I.
} 
years. Gordon has managed to go through at least one book and often two books, every day. ${ }^{6}$ Librarians could hardly be expected to have so high an absorptive capacity, since they do have a few other chores to do than reading.

It is anybody's guess as to how many books are read by the average collegeeducated person in the United States a year. But it is doubtful whether he currently reads more than two or three volumes a month, or about 30 volumes a year. At this rate, a librarian, reading a total of 100 volumes a year, would read well over three times as much. After 25 years of employment, a librariąn would have outstripped the average college-educated person by about I 750 volumes (see Table I). Thus by the time he approached the ripe age of 50, he could truly claim to be well-read on the basis of quantity alone (2500) and in contrast to his college-educated fellow citizens who had read less ( 750 volumes).

If authorized library reading programs should become universal, even those librarians who wished to read on their own time no more than the average collegeeducated person ( 30 volumes a year) could be expected to accumulate a reading record

Merle Miller, "! ! ! aba? ? ?" Saturday Review of Literature, 34:20-2I (Feb. I0, I95I). of 70 volumes a year. At the age of 50 , such a librarian would have read Iooo volumes more than the average college-educated person, or a total of I 750 volumes, which is probably several times as many as an average high school graduate reads in a life-time.

In stressing quantity, we should not underestimate the importance of quality of consumption. It would be assumed that the books had been carefully read and with adequate comprehension, that the bulk of the titles would fall outside the categories of mystery, detective, Western stories, and light romances, and that, in public libraries, a fair balance between good fiction and nonfiction had been maintained. Being college graduates, professional librarians could be expected to be judicious in the choice of their reading matter for their hours of leisure.

As for the 40 books a year to be read on library time, careful selection is imperative. At the average 1952 salary of $\$ 3,768$ a year for a professional librarian, the cost of the reading program to the library would be $\$ 942$ per librarian per year or $\$ 23.55$ per book read. ${ }^{7}$ Such a relatively high unit cost can be defended only if books are se-

7 The median monthly salary of professional librarians in the U. S., in effect March 1 , I952, was reported to be $\$ 3$ I 4 , which would amount to $\$ 3,768$ per year if the

Table I

Estimated Reading Records

\begin{tabular}{|c|c|c|c|c|c|}
\hline \multirow[b]{2}{*}{ Type of Reader } & \multicolumn{3}{|c|}{ Volumes Read Annually } & \multirow{2}{*}{$\begin{array}{l}\text { Total } \\
\text { Volumes } \\
\text { Read after } \\
25 \text { years }\end{array}$} & \multirow{2}{*}{$\begin{array}{c}\text { Gain over } \\
\text { average college } \\
\text { graduate after } \\
25 \text { years }\end{array}$} \\
\hline & $\begin{array}{l}\text { During } \\
\text { Leisure } \\
\text { Hours }\end{array}$ & $\begin{array}{l}\text { On } \\
\text { Paid } \\
\text { Time }\end{array}$ & Total & & \\
\hline Average College Graduate & 30 & $\longrightarrow$ & 30 & 750 & - \\
\hline $\begin{array}{l}\text { No Reading Program Authorized } \\
\text { Non-Ambitious Librarian } \\
\text { Ambitious Librarian }\end{array}$ & $\begin{array}{l}30 \\
60\end{array}$ & - & $\begin{array}{l}30 \\
60\end{array}$ & $\begin{array}{r}750 \\
1,500\end{array}$ & 750 \\
\hline $\begin{array}{l}\text { Reading Program Authorized } \\
\text { Non-Ambitious Librarian } \\
\text { Ambitious Librarian }\end{array}$ & $\begin{array}{l}30 \\
60\end{array}$ & $\begin{array}{l}40 \\
40\end{array}$ & $\begin{array}{r}70 \\
100\end{array}$ & $\begin{array}{l}1,750 \\
2,500\end{array}$ & $\begin{array}{l}1, \infty 00 \\
1,750\end{array}$ \\
\hline Professional Book Reviewer & - & 500 & 500 & 12,500 & I I , 750 \\
\hline
\end{tabular}


lected according to a clearly formulated policy appropriate to the library in question. The difficulty of selecting the relevant titles from the multitude of publications has probably been one of the major hurdles in the inauguration and operation of any staff reading program. However, this difficulty should constitute a challenge to the alert administrator rather than an unsurmountable obstacle.

About fifty years ago, it was quite popular to quote the paradoxical epigram, "The librarian who reads is lost."8 The epigram is still occasionally quoted among librarians today to cover up the deep frustration felt as a result of the lack of the time for reading among librarians. ${ }^{9}$ It has been suggested that the phrase be reworded to read: "The librarian is lost who does not read wisely." ${ }^{10}$ Both the original and the rephrased versions reflect the common experience of librarians who are overwhelmed by the never-ending flow of publications; librarians cannot possibly expect to digest very much of it. It is perhaps natural to react to such an unmanageable situation by feeling that, no matter how much an individual librarian may read, he can at best cover only an infinitesimal fraction of the total publishing output or of the acquisitions of

librarian worked 12 months in a year (Hazel B. Tim merman, "Library Salaries, 1952," $A L A$ Bulletin, 46:

340, November 1952). ${ }_{8}$ G. M. Walton, "The Lost Librarian," New York Public Library. Bulletin, 29:530 (1925).

${ }^{9}$ The epigram was first applied to Isaac Casaubon, the learned librarian of King Henry the Fourth of France, by his biographer, the Rev. Mark Pattison, of I incoln College, Oxford. Casaubon was accused of having neglected his library duties in the pursuit of studies that were not related to his professional library work th Wilberforce Eames, "What Should Librarians Read?" Library Journal, 25:60 (Feb. 1900). any given library. The larger the library, the greater the frustration, until a point is reached where reading almost nothing at all seems, superficially, to have no deleterious effect on his assigned library duties. The little reading an ambitious library assistant may find time for during his leisure hours does not seem to have any very noticeable beneficial effect on his work performance in a busy library, either. From such observations it is easy enough to conclude that, since reading seems to make so little tangible difference, librarians might as well dispense with it altogether, or, at best, read no more than the average collegeeducated citizen. According to the testimony of librarians and in the absence of any published protestations to the contrary, such appears to be the state of affairs among the vast majority of librarians today.

The day may come when library administrators will recommend a work schedule for staff members which will allow for a liberal amount of official reading under competent supervision as part of the regular work week. It was shown that such a revolutionary change can be accomplished only by curtailing the current program of a given library or by increasing the library budget.

On the surface, such a change will not produce any immediate spectacular results. Over the years, however, the effect on service to the public, staff competence, staff morale, and recruiting for the profession of librarianship is certain to be deep and farreaching.

\section{ACRL Microcard Series}

The ACRL Publications Committee announces the inauguration of an ACRL Microcard Series. It will consist of longer studies in all fields of library science (not necessarily college and university librarianship) which are not suitable for publication in any of the existing media. They will be subjected to the same editorial scrutiny that is in effect for College $\xi^{\circ}$ Research Libraries and the ACRL Monographs. Manuscripts should be submitted to Lawrence S. Thompson, chairman, ACRL Publications Committee, University of Kentucky Libraries, Lexington, Kentucky. 